\title{
ACUTE EFFECTS OF SYNTHETIC CANNABINOIDS ON VENTRICULAR REPOLARIZATION
}

\author{
Uguz Berat, ${ }^{1}$ Tiryakioglu Kenar Selma, ${ }^{1}$ Dal Evren, ${ }^{2}$ Tihan Kivrak Aysu, ${ }^{3}$ \\ Yalin Kivanc, ${ }^{4}$ Ozkan Hakan ${ }^{5}$ \\ ${ }^{1}$ Bursa City Hospital, Department of Cardiology, Bursa, Turkey \\ ${ }^{2}$ Bursa City Hospital, Department of Emergency, Bursa, Turkey \\ ${ }^{3}$ Bursa City Hospital, Department of Psychiatry, Bursa, Turkey \\ ${ }^{4}$ Istanbul University Cerrahpasa Medical Faculty, Department of Cardiology, Istanbul, Turkey \\ ${ }^{5}$ Medicana Hospital, Department of Cardiology, Bursa, Turkey
}

Primljen/Received 09. 07. 2020. god.

Abstract: Objective: The usage of synthetic cannabinoids (SCs) has increased both in Turkey and all worldwide. Here, we evaluate if SCs cause ventricular repolarization abnormalities using initial and after $12^{\text {th }}$-hour electrocardiograms in patients with acute intoxication of SCs. We examined changes in the QTc and cTp-e parameters to demonstrate ventricular repolarization effects of the usage of SCs.

Material and Methods: We used a prospective study design. Twenty patients were included who visited the emergency department, complaining of clouding of consciousness after using SCs. The QT, QTc and Tp-e intervals and several other electrocardiographic parameters were measured at baseline and 12 hours after the usage of SCs.

Results: The QRS duration was significantly decreased $(102.1 \pm 15.5 \mathrm{~ms}$ vs $95.0 \pm 10.7 \mathrm{~ms} ; \mathrm{p}=0.022)$. We noted a significant decrease in cQT measurements at the end of the $12^{\text {th }}$ hour $(426.6 \pm 47.2 \mathrm{~ms}$ vs $390.4 \pm$ $42.9 \mathrm{~ms} ; \mathrm{p}=0.002$ ). Similarly, the Tp-e and cTp-e values decreased significantly when SCs lost its acute effect $(93.4 \pm 21.1 \mathrm{~ms}$ vs $77.4 \pm 21.0 \mathrm{~ms} ; \mathrm{p}=0.014,105.3$ $\pm 28.5 \mathrm{~ms}$ vs $88.1 \pm 21.5 \mathrm{~ms} ; \mathrm{p}=0.01$ ).

Conclusions: The usage of SCs affects ventricular repolarization heterogeneity based on QTc and Tp-e intervals.

Keywords: Synthetic cannabinoids, Bonzai, ventricular repolarization heterogeneity, adverse cardiovascular effects.

\section{INTRODUCTION}

The usage of synthetic cannabinoids (SCs) has increased both in Turkey and all over the world. Synthe-
Prihvaćen/Accepted 26. 09. 2020. god.

tic cannabinoids are psychoactive substances showing similar agonistic effects on $\mathrm{SC}$ receptors such as $\Delta 9$-tetrahydrocannabinole $(\Delta 9-\mathrm{THC})$, which is the active metabolite of cannabis (1). It has become more attractive than natural cannabinoid (i.e., marijuana) because they are easily accessible, cheap and cannot be detected in blood using a routine toxicological examination. Synthetic cannabinoids are widely used and sold in many countries around the world. It is not accurate to say that each of these brands is restricted to the region indicated. Synthetic cannabinoids can be sold as 'Spice' in Europe, 'K2' in the United States or 'Bonzai' or 'Jamaica' in Turkey (2). More than 140 products have been defined that include SCs (3). All of these products have different amounts and types of SCs and may include psychoactive materials except SCs or substances expressing adrenergic effects. The potency and the short half-life of SCs results in powerful effects. However, the heterogeneous structure of SCs results indifferent clinical effects $(4,5)$. Hoyte et al. (6) reported that the well-defined side effects of SCs include nausea (in 10\% of cases), vomiting (15.3\%), tachycardia $(40.0 \%)$, bradycardia $(1.3 \%)$, hypertension $(8.1 \%)$, chest pain $(4.7 \%)$, anxiety (23.4\%), dizziness/lethargy (7.3\%) in a study of 1353 individuals (6). Some of the cases presented only cardiac symptoms. Acute ischemia, ventricular fibrillation and intracranial events have been responsible for the death of patients using SCs. Recently studies have demonstrated the inhibitor effects of cannabinoids on myocardial voltage-gated sodium channels and L-type calcium channels independent of sympathetic nervous system effects $(7,8)$. 
In this study, we evaluated whether SCs were responsible for ventricular repolarization abnormalities using initial and 12th-hour electrocardiograms (ECGs) in patients with acute intoxication resulting from SCs. We examined changes in the QTc and cTp-e parameters to demonstrate the ventricular repolarization effects of the usage of SCs.

\section{MATERIAL AND METHODS}

\section{Patient population}

The 20 patients included in this study presented clouding of consciousness after using SCs when they visited the emergency department. Patients with a history of any cardiac disease, liver failure or kidney failure were excluded. Patients using multiple drugs (e.g., ecstasy, cocaine, etc.) were excluded as well. All of the patients were smokers with normal biochemical results in the laboratory which effect the repolarization such as calcium and potassium. Because of the importance of the duration of 'Bonzai' usage, only patients who remembered how long they had used 'Bonzai' were enrolled in this study. All of the patients were carefully evaluated for coronary ischemia. We evaluated ECGs, symptoms and consecutive cardiac markers to rule out acute coronary syndrome. Two patients with coronary ischemia underwent a coronary angiography and were excluded from the study. Written, informed consent was obtained from each subject, and the institutional Ethics Committee approved the study protocol (Ethics Committee of Bursa Yuksek Ihtisas Education and Research Hospital; 2011-KAEK-25 2016/01-07). All procedures performed in study were in accordance with the Helsinki declaration.

\section{Study design}

Standard 12-lead ECGs were recorded on a 12-channel electrocardiography recorder ( Cardipia 800, Trismed, Republic of Korea ) for all of the patients in the emergency department. The study was prospectively designed and second ECGs were obtained at the end of the $12^{\text {th }}$ hour according to the declaration of the usage of 'Bonzai.' All of the ECG recordings were scanned and transferred to a computer and then magnified 300 times using Adobe Photoshop (Location) software. Only one observer who was unaware of the patients' clinical status measured the intervals and durations. The QT intervals were measured from the onset of QRS to the end of the T wave. When the end of the T wave could not be reliably identified, the lead was not included in the analysis. Four consecutive QT intervals in each of the six precordial leads were measured and averaged. The QT interval was corrected for heart rate using the Bazett formula: $\mathrm{QT} / \% \mathrm{R}-\mathrm{R}(\mathrm{cQT})$. We measured the Tp-e intervals from the peak of the T wave to the end of the T wave. Similarly, we corrected the Tp-e interval (cTp-e) for heart rate using the RR interval: (Tp-e /\%R-R).

\section{Statistical analysis}

All of the data are presented as mean values \pm standard deviation (SD). Comparisons between two ECGs baseline and after $12^{\text {th }}$ hours were performed using paired and unpaired Student's t-tests. A p value less than 0.05 was considered to be statistically significant. All of the statistical calculations were performed using the Statistical Package for Social Sciences 19.0 for Windows (SPSS Inc., Chicago, IL, USA) statistical software package.

\section{RESULTS}

Patients admitted to the emergency department with a history of recent usage of SCs were included to the study. 10 patients (50\%) experienced loss of consciousness within one hour and somnolence after a few hours. We noted syncope in 3 patients and somnolence $(15 \%)$, confusion and disorientation in 5 patients (25\%).1 patient was admitted with bradycardia and hypotension and one presented only bradycardia. In addition, nausea, vomiting, dizziness and drowsiness were frequently observed in the patients. All of the patients exhibited signs of agitation, anxiety and hallucination to differing degree. The mean age of the 20 patients was 22 \pm 4.5 years. All of the patients were male. The mean elapsed time between SCs usage and hospital admission was $180 \pm 24 \mathrm{~min}$. None of the patients exhibited a hypertensive response. At the end of the $12^{\text {th }}$ hour, the patients' mean blood pressure tended to decrease because the effect of SCs had nearly ceased. However, it was not statistically significant. The patients' mean heart rate was $76.2 \pm 15.5$ beats per minute (bpm). The patients' mean heart rate at the end of the $12^{\text {th }}$ hour was $71.8 \pm$ $13.3 \mathrm{bpm}$ (non-significant). Neurologists and internal medicine specialists consulted with all of the patients. The subjects were followed-up in the hospital unit for 24 hours. All of the patients were referred to the psychiatry department for further evaluation.

The mean PR intervals was $149.071 \pm 27.7 \mathrm{msec}$, and the mean QRS duration was $102.143 \pm 15.5 \mathrm{msec}$. When SC lost its acute effect, the mean PR interval was $140.1 \pm 20.4 \mathrm{~ms}$. However, it was not statistically significant.

However, the QRS duration was significantly decreased $(102.1 \pm 15.5 \mathrm{~ms}$ vs $95.0 \pm 10.7 \mathrm{~ms} ; \mathrm{p}=0.022)$. When we evaluated the cQT measurements, we noted a significant decrease at the end of the $12^{\text {th }}$ hour $(426.6 \pm$ $47.2 \mathrm{~ms}$ vs $390.4 \pm 42.9 \mathrm{~ms} ; \mathrm{p}=0.002$ ). Similarly, the Tp-e and cTp-e values decreased significantly when SC lost its acute effect $(93.4 \pm 21.1 \mathrm{~ms}$ vs $77.4 \pm 21.0$ 
Table 1. Hemodynamic and electrocardiographic findings on admission and at the 12 th hour

\begin{tabular}{|l|c|c|c|}
\hline \multirow{2}{*}{} & Baseline & $\mathbf{1 2}^{\text {th }}$ hour later & \multirow{2}{*}{$\begin{array}{c}\text { p } \\
\text { value }\end{array}$} \\
\cline { 2 - 3 } & $\begin{array}{c}\text { mean SD } \\
(\mathrm{n}=20)\end{array}$ & $\begin{array}{c}\text { mean SD } \\
(\mathrm{n}=20)\end{array}$ & NS \\
\hline Heart rate (bpm) & $76.2 \pm 15.5$ & $71.8 \pm 13.3$ & NS \\
\hline Systolic BP (mmHg) & $128 \pm 6.9$ & $121 \pm 6.1$ & NS \\
\hline Diastolic BP (mmHg) & $78 \pm 6.1$ & $72 \pm 5.9$ & NS \\
\hline PR interval (ms) & $149.0 \pm 27.7$ & $140.1 \pm 20.4$ & 0.022 \\
\hline QRS duration (ms) & $102.1 \pm 15.5$ & $95.0 \pm 10.7$ & NS \\
\hline QTinterval (ms) & $382.1 \pm 42.2$ & $376.0 \pm 36.0$ & 0.002 \\
\hline QTc interval (ms) & $426.6 \pm 47.2$ & $390.4 \pm 42.9$ & 0.014 \\
\hline Tp-e (ms) & $93.4 \pm 21.1$ & $77.4 \pm 21.0$ & 0.010 \\
\hline cTp-e (ms) & $105.3 \pm 28.5$ & $88.1 \pm 21.5$ & \\
\hline
\end{tabular}

BP: Blood pressure, bpm: Beats per minute, ms: millisecond, NS: Non-significant.

$\mathrm{ms} ; \mathrm{p}=0.014,105.3 \pm 28.5 \mathrm{~ms}$ vs $88.1 \pm 21.5 \mathrm{~ms} ; \mathrm{p}=$ 0.01 ). All of the data are presented in Table 1.

\section{DISCUSSION}

We evaluated the effects of SCs, which are increasingly popular around the world, on ventricular repolarization. Synthetic cannabinoids have become a serious problem because they were legal when they were first released. Additionally, they cannot be detected in screening tests, and there is the perception that they are safer than marijuana. More than 140 products are defined as containing SCs $(3,5)$, and they vary according to the type and amount of SCs. Synthetic cannabinoids are being sold with a combination of dried herbs after being synthesized in the laboratory as an alternative to marijuana (5). In Turkey, the name 'Bonzai' is used occasionally to refer to SCs (5). Hermanns-Clausen et al. declared that the usage of JWH-018 was abandoned in SC-containing products; JWH-122 and JWH-210 were used instead after 2011 (9). In contrast of this study, we found JWH-018 substance when scanned recent studies from Turkey about 'Bonzai'.JWH-018 in 1174 out of 1179 cases $(99.4 \%)$ in a report published by Gurdal et al. (4). In addition, 777 cases (65.9\%) contained both JWH-081 and JWH-018. Dynamic changes in active ingredients are observed over time throughout the world. However, all of these substances are derived from the SC family and likely result in effects on similar receptors.

Synthetic cannabinoids were developed to achieve the curative effects. These substances bind to the $\mathrm{CB} 1$ and $\mathrm{CB} 2$ receptors and exhibit similar effects as tetrahydrocannabinol, which is the active substance in marijuana (5). The CB1 receptors are primarily localized in the central and peripheral nervous system. Activation of $\mathrm{CB} 1$ receptors changes mood and perception, and continued cannabis consumption elicits addictive behavior (9). The CB2 receptors are largely localized in the immune system. Synthetic cannabinoids have typically agonistic effects on CB1 receptors. Synthetic cannabinoids have a stronger affinity to $\mathrm{CB} 1$ receptors, which makes them more powerful than $\triangle 9 \mathrm{THC}(10$, 11). There are different usage presentations of SC, and some effects are associated with the cardiovascular system. A first effect is myocardial ischemia. There is few mechanisms known to be responsible for myocardial infarction due to the usage of addictive substances (11). A 2001 study by Mittleman et al. presented clear evidence for a relationship between marijuana and myocardial infarction (12). This can be explained by norepinephrine release and stimulation of the sympathetic system. Myocardial $\mathrm{O}_{2}$ demands increase with tachycardia induced by the stimulation of the sympathetic system, which results in ischemia. In addition, norepinephrine release with sympathetic nervous system stimulation results in vasoconstriction and worsening of myocardial ischemia (11). In our series, one patient exhibited vasospastic angina, and another exhibited atherosclerotic plaque rupture in coronary angiograms. However, our goal was to evaluate ventricular repolarization dynamics independent of acute coronary ischemia. Therefore, we excluded these two patients from our study. All of the patients that evaluated showed symptoms including angina and equivalents of angina, ECG and cardiac marker analysis. Only patients without ischemia enrolled in the study; patients with ischemia or suspicions of ischemia were excluded from the study. The second effect of SCs ranges from myocardial depression to conduction abnormalities via cannabinoids receptors. These effects result from the strong binding of cannabinoids to CB1 receptors. This action mechanism of SCs on cannabinoid receptors may cause bradycardia, tachycardia, hypotension, hy- 
pertension, seizures and QT prolongation $(13,14)$. Kucuk et al., in a study conducted in Turkey, reported that 37 out of 112 patients had cardiac side effects. Nineteen of these patients $(20 \%)$ had chest pain and 18 out of the 112 patients (16\%) presented palpitation (15). One patient presented bradycardia and hypotension, and another patient presented bradycardia alone. Initial blood pressure and heart rate were higher in the remaining 18 patients compared with the values at the end of the $12^{\text {th }}$ hour. However, this finding was not statistically significant. The effects of endocannabinoids on contractility and calcium signaling have been shown via both cannabinoid receptors and a direct effect on ion channels (14). Small studies have suggested that endogenous cannabinoids such as anandamide show negative inotropic and antiarrhythmic effects using voltage gate sodium channels and L-type calcium channels independent from sympathomimetic activity $(7,8)$. Animal studies have demonstrated that SCs cause bradycardia; in particular, HU-210 had a negative chronotropic effect (13). Bui et al. reported a case of marijuana with QT prolongation upon initial admission. In this case report, pathological QT prolongation was determined with the usage of marijuana in 34-year-old female patient (16). Von Der Haar et al. (14) reported a two different cases QT prolongation due to usage of SCs. These cases raise concerns about the adverse effects of SCs and the possibility of QTc prolongation and subsequent complications when using antipsychotic medication in the presence of SC abuse (13). The QT and cQT intervals were significantly prolonged compared with the end of the acute effect of SCs in our cases. QT prolongation may be harmful in patients with underlying disease such as coronary artery disease and rhythm abnormalities such as hereditary or acquired long QT syndromes. In these subjects, QT intervals may attain the critical values and be life-threatening with the usage of SC.

Recent studies have demonstrated that the Tp-e interval, which is the terminal part of QT interval and defined as the duration from the peak to the end of the T wave, is a useful index for evaluating cardiac repolarization (17). Siciouri et al. (17) described the relation between ventricular arrhythmias and the Tp-e interval. The middle myocardial $\mathrm{M}$ cells have a longer action potential duration then other cells. The peak of the $\mathrm{T}$ wave exhibits the terminal part of epicardial action potential where the end of the $\mathrm{T}$ wave shows the end of the mid-myocardial action potential (17). Therefore, the Tp-e interval is a reflection of the dispersion of repolarization and can be helpful for predicting the risk of developing life-threatening arrhythmias (18). This hypothesis was studied and evidenced in patients with hypertrophic cardiomyopathies (19), arrhythmogenic right ventricular dysplasia (20) and other pathophysiological conditions. In our study, we examined the $\mathrm{Tp}$-e and cTp-e intervals immediately after the usage of SC. The data before and after SC were significantly different. The Tp-e and cTp-e intervals were significantly prolonged with the usage of SC. The prolongation of the Tp-e and cTp-e intervals is important for predicting ventricular repolarization abnormalities. In our study, there were no life-threatening arrhythmias detected during the follow-up period, which was only approximately 12 hours. However, overdose or chronically usage may induce lethal arrhythmias and cause prolongation of ventricular repolarization.

\section{Study limitations}

The most substantial limiting factor of this study was that the substance was not toxicologically classified. Verbal statements of patients who visited the emergency department were taken as truth; patients who stated that they used multiple drugs were excluded from the study. For active substances, failure to achieve identification in a toxicology laboratory was the most substantial limiting factor of this study. Routine screening tests for SCs are not being utilized yet in hospitals of the Ministry of Health (i.e., our clinic). Another limiting factor was the small number of patients. The primary explanation for our small cohort of patients was that a large fraction the patients declared that they used multiple drugs; these individuals were accordingly excluded from the study. The illegality of SC made it difficult to recruit participants and follow up on cases.

\section{CONCLUSIONS}

We have demonstrated that the use of SCs slows down ventricular repolarization and lengthens the QTc, Tp-e and cTp-e intervals clinically. This situation may result in the lengthening of the QT interval in pathological limits and the development of vital arrhythmias in patients with underlying ischemic heart diseases or patients with long QT syndrome. Some of cardiac-related deaths may be correlated with ischemia, and some of them may be dependent on arrhythmia. Additional electrophysiological studies are required to address this issue.

\section{Abbreviations \\ SCs - synthetic cannabinoids \\ ECGs - electrocardiograms}

Conflict of Interests: The authors declare that there are no conflicts of interest related to this article.

Funding: None

\section{Licensing}

This work is licensed under a Creative Commons Attribution 4.0 International (CC BY 4.0) License. 


\title{
Sažetak
}

\section{AKUTNI EFEKTI SINTETSKIH KANABINOIDA NA VENTRIKULARNU REPOLARIZACIJU}

\author{
Uguz Berat, ${ }^{1}$ Tiryakioglu Kenar Selma, ${ }^{1}$ Dal Evren, ${ }^{2}$ Tihan Kivrak Aysu, ${ }^{3}$ \\ Yalin Kivanc, ${ }^{4}$ Ozkan Hakan ${ }^{5}$ \\ ${ }^{1}$ Bursa City Hospital, Department of Cardiology, Bursa, Turkey \\ ${ }^{2}$ Bursa City Hospital, Department of Emergency, Bursa, Turkey \\ ${ }^{3}$ Bursa City Hospital, Department of Psychiatry, Bursa, Turkey \\ ${ }^{4}$ Istanbul University Cerrahpasa Medical Faculty, Department of Cardiology, Istanbul, Turkey \\ ${ }^{5}$ Medicana Hospital, Department of Cardiology, Bursa, Turkey
}

Uvod: Upotreba sintetskih kanabinoida je u porastu, kako u Turskoj, tako i širom sveta. U ovoj studiji, evaluirali smo da li sintetski kanabinoidi izazivaju poremećaj ventrikularne repolarizacije analizom inicijalnog elektrokardiograma i elektrokardiograma nakon $12 \mathrm{~h}$, kod pacijenata sa akutnom intoksikacijom sintetskim kanabinoidima. Pratili smo promene QTc i cTp-e parametara kako bi demonstrirali uticaj sintetskih kanabinoida na ventrikularnu repolraizaciju.

Materijal i Metode: Sproveli smo prospektivnu studiju. Uključeno je 20 pacijenata koji su posetili hitnu službu, žaleći se na pomućenje svesti nakon konzumiranja sintetskih kanabinoida. QT, QTc i cTp-e intervali i određeni elektrokardiografski parametri inicijalnog elektrokardiograma i elektrokardiograma nakon $12 \mathrm{~h}$ su mereni.

\section{REFERENCES}

1. EMCDDA. Synthetic perspectives on drugs. Cannabinoids in Europe. http://www.emcdda.europe.eu/attachements.cfm/att_212361_EN_EMCDDA_POD_2013-synthetic\%20cannabinoids.pdf.

2. Evren C, Bozkurt M. Sentetik kannabinoidler: Son yollarin krizi. Dusunen Adam The Journal Of Psychiatry and Neurological Sciences. 2013; 26(1): 1-11.

3. Lewin AH, Seltzman HH, Caroll FI, Mascarella SW, Reddy A. Emergence and properties of spice and bath salts. A medicinal chemistry perspective. Life Sci 2014; 97(1): 9-19.

4. Gurdal F, Asirdizer N, Aker RG, Korkut S, Gocer Y, Kucukibrahimoglu EE et al. Review of detection frequency and type of synthetic cannabinoids in herbal compounds analyzed by astanbul Narcotic Department of the council of Forensic Medicine, Turkey. J Forensic Leg Med. 2013; 20(6): 667-72.

5. Bozkurt M, Umut G, Evren C, Karabulut V. Sentetik kannabinoid kullanimi nedeniyle poliklinige basvuran hastalarin klinik ozellikleri ve laboratuvar sonuclar2. Dusunen Adam The Journal Of Psychiatry and Neurological Sciences. 2014; 27 : $328-34$.

6. Hoyte CO, Jacob J, Monte AA, Al-Jumaan M, Bronstein AC, Heard KJ. Characterization of synthetic cannabinoids exposures reported to the National Poison Data system in 2010. Ann Emerg Med. 2012; 60(4): 435-8.

7. Al Kury LT, Voitychuk OI, Yang KH, Thayyullathil FT, Doroshenko P, Ramez AM, et al. Effects of the endegenous can-
Rezultati: QRS interval je bio značajno produžen $(102.1 \pm 15.5 \mathrm{~ms}$ vs $95.0 \pm 10.7 \mathrm{~ms} ; \mathrm{p}=0.022)$. Zapaženo je i značajno produženje cQT intervala na kraju 12 og sata $(426.6 \pm 47.2 \mathrm{~ms}$ vs $390.4 \pm 42.9$ $\mathrm{ms} ; \mathrm{p}=0.002)$. Slično, Tp-e i cTp-e vrednosti značajno su porasle kada su sintetski kanabinoidi izgubili svoj akutni efekat $(93.4 \pm 21.1 \mathrm{~ms}$ vs $77.4 \pm$ $21.0 \mathrm{~ms} ; \mathrm{p}=0.014,105.3 \pm 28.5 \mathrm{~ms}$ vs $88.1 \pm 21.5$ $\mathrm{ms} ; \mathrm{p}=0.01)$.

Zaključak: Konzumiranje sintetskih kanabinoida utiče na heterogenost ventrikularne repolarizacije sudeći po QTc i Tp-e intervalima.

Ključne reči: sintetski kanabinoidi, Bonzai, heterogenost ventrikularne repolarizacije, negativni kardiovaskularni efekti.

nabinoid anandamide on voltage-dependent sodium and calcium channels in rat ventricular myocytes. Br J Pharmacol. 2014; 171(14): 3485-98.

8. Krylatov AV, Maslov LN, Ermakov SYu, Lasukova OV, Barzakh EI, Crawford D, et al. Significance of cardiac cannabinoid receptors in regulation of cardiac rhythm, myocardial contractility and electrophysiologic processes in heart. Izvestiya Akademii Nauk, Seriya Biologicheskaya. 2007; 1: $35-44$.

9. Hermanns-Clausen M, Kneisel S, Szabo B, Auwarter V. Acute toxicity due to the confirmed consumption of synthetic cannabinoids: clinical and laboratory findings. Addiction 2013; 108(3): 534-44.

10. Huffman JW, Padgett LW. Recent developments in the medical chemistry of cannabinomimetic indoles, pyrroles and indices. Curr Med Chem. 2005; 12(12): 1395-441.

11. Atık SU, Dedeoglu R, Varol F, Cam H, Eroglu AG, Saltık L. Cardiovascular side effect related with use of synthetic cannabinoids 'Bonzai': two case reports. Turk Pediatri Ars. 2015; 50(1): 61-4.

12. Mittleman MA, Lewis RA, Malcolm M, Sherwood JB, Muller JE. Triggering myocardial infarction by marijuana Circulation. 2001; 103(23): 2805-9.

13. Young AC, Schwarz E, Medina G, Obafemi A, Feng S, Kane C, et al. Cardiotoxicity associated with the synthetic cannobinoid, K9; with laboratory confirmation. Am J Emerg Med. 2012; 30(7): 1320.e5-7. doi: 10.1016/j.ajem.2011. 05.013 . 
14. Von Der Haar J, Talebi S, Ghobadi F, Singh S, Chirurgi $\mathrm{R}$, Rajeswari P, et al. Synthetic cannabinoids and their effects on the cardiovascular system. J Emerg Med. 2016; 50(2): 258-62.

15. Kucuk E, Kucuk I, Yildiz Y, Kirazaldi YY. Acil serviste yeni bir tehlike: Sentetik kannabinoidler (Bonzai, Jameika). Genel T2p Derg. 2015; 25: 18-22.

16. Bui QM, Simpson S, Nordstam K. Psychiatric and medical management of marijuana intoxication in the emergency department. West J Emerg Med. 2015; 16(3): 414-7.

17. Sicouri S, Atzelevitch C. A subpopulation of cells with unique electrophysiological properties in the deep subepicardium of the canine ventricle. The M Cell Circ Res. 1991; 68(6): $1729-41$.
18. Mac Cornack FA. The effects of coffee drinking on the cardiovascular system: experimental and epidemiological research. Prev Med. 1977; 6(1): 104-19.

19. Shimizu M, Ino H, Okeie K, Yamaguchi M, Nagata M, Hayashi K.et al. T-peak to T-end interval may be a better predictor of high risk patients with hypertrophic cardiomyopathy associated with cardiac troponin I mutation than QT dispersion. Clin Cardiol. 2002; 25(7): 335-9.

20. Golcuk E, Yal2n K, Kaya BA, Elitok A, Aksu T, Karaayvaz $\mathrm{B}$, et al. Usefulness of $\mathrm{T}$ (peak)- $\mathrm{T}$ (end) interval to distinguish arrhythmogenic right ventricular cardiomyopathy from idiopathic right ventricular outflow tract tachycardia. Pacing Clin Electrophysiol. 2014; 37(12): 1665-70.

\section{Correspondence to/Autor za korespondenciju}

Uguz Berat

T.C. Sağlık Bakanlığ1 Bursa Şehir Hastanesi Doğanköy Mahallesi, 16110 Nilüfer/BURSA

email: beratuguz33@hotmail.com 